\title{
Penyuluhan Pembuatan Microorganisme Local Bagi Warga Desa Brengkol Guna Mengurangi Penggunaan Pupuk Kimia Pada Pertanian
}

\author{
Muhammad Hafiz ${ }^{1}$, Surya Aji Wibowo², Wahyu Purbaningsih ${ }^{3}$, Sriyono ${ }^{3^{*}}$ \\ Universitas Muhammadiyah Purworejo \\ Jl. KHA. Dahlan 3 dan 6 Purworejo, Jawa Tengah, Indonesia \\ *email: sriyono@umpwr.ac.id
}

\begin{abstract}
Abstrak - Mayoritas pertanian saat ini menggunakan pupuk kimia. Meskipun efektif dalam menyuburkan tanaman, namun dampak jangka panjangnya dapat merusak ekosistem persawahan dan lahan pertanian itu sendiri. Penyubur tanaman memanfaatkan mikro bioorganisme lokal menjadi solusi bagi petani lokal, menuju pertanian ramah lingkungan dan bebas dari pupuk dan obat-obatan kimiawi. Tujuan kegiatan ini adalah (1) Memanfaatkan limbah organik sebagai bahan pembuatan microorganisme local, (2) Menghindari penggunaan pupuk kimia agar hasil tanaman layak dikonsumsi, (3) Menginformasikan pemanfaatn limbah organik sebagai bahan microorganisme local terhadap petani. Kegiatan ini dilaksanakan pada tanggal 30 Januari 2017, bertempat di aula balai desa Brengkol, kecamatan Pituruh, pukul 08.00 WIB. Metode pelaksanaan yaitu penyuluhan, mengintroduksikan bahan limbah organik dan pembuatan micoorganisme local. Hasil kegiatan pembuatan microorganisme local di desa Brengkol kecamatan Pituruh menunjukan: (1) Kegiatan ini dihadiri oleh perangkat desa, petani, karang taruna dan tohoh masyarakat, (2) Peserta yang mengikuti kegiatan ini antusias dan sangat termotivasi dengan penyampaian materi dan praktik sehingga dengan penyampaian materi dan praktik pembuatan MOL peserta diharapkan bisa mempraktekan sendiri.
\end{abstract}

Kata kunci: pengembangan pertanian ramah lingkungan, pertanian organik, $M O L$

\section{Training on Making Local Microorganisms for Residents of Brengkol Village to Reduce the Use of Chemical Fertilizers in Agriculture}

\begin{abstract}
The majority of agriculture today uses chemical fertilizers. Although it is effective in fertilizing crops, its long-term impact can damage the rice fields ecosystem and agricultural land itself. Plant fertilizers utilize local micro-organisms as a solution for local farmers, towards environmentally friendly agriculture and free from fertilizers and chemical drugs. The objectives of this activity are (1) Utilizing organic waste as material for local microorganisms, (2) Avoiding the use of chemical fertilizers so that crop products are suitable for consumption, (3) Informing farmers about the use of organic waste as materials for local microorganisms. This activity was held on January 30, 2017, at the Brengkol village hall, Pituruh sub-district, at 08.00 WIB. The implementation method is counseling, introducing organic waste materials and making local microorganisms. The results of the activity of making local microorganisms in the village of Brengkol, Pituruh sub-district showed: (1) This activity was attended by village officials, farmers, youth organizations and community members, (2) Participants who took part in this activity were enthusiastic and very motivated by delivering materials and practices so that the delivery It is hoped that the material and practice of making MOL participants can practice on their own.
\end{abstract}

Keywords: development of environmentally friendly agriculture, organic farming, $M O L$ 


\section{PENDAHULUAN}

Pengembangan pertanian yang ramah lingkungan merupakan keharusan demi kelangsungan produksi dan kesehatan. Upaya-upaya tersebut telah direkomendasikan oleh pemerintah, salah satu usaha yang dilakukan adalah dengan melakukan usaha pertanian secara organik. Pertanian organik merupakan sistem pertanian berkelanjutan dengan menekankan pada kestabilan lingkungan. Indikator kestabilan pertanian organik tersebut dapat diketahui dari keragaman dan kelimpahan serangga salah satunya serangga nokturnal (Rudi, dkk, 2013).

Pupuk adalah zat, baik sistetis atau organik, yang ditambahkan ke tanah untuk meningkatkan pasokan nutrisi penting yang meningkatkan pertumbuhan tanaman dan vegetasi di dalam tanah. Meski ditujukan untuk memberikan keuntungan bagi manusia, namun dampak dari kegiatan pemupukan pada tanah perlu diperhatikan. Penggunaan pupuk kimia yang berlebihan justru merusak tekstur tanah itu sendiri. Hal ini khususnya pada penggunaan pupuk kimia. Jika dilakukan secara berlebihan, penggunaan pupuk kimia bisa menimbulkan dampak yang justru merusak kesuburan tanah itu sendiri dan bukan menjadikannya subur. Pupuk kimia adalah pupuk yang dibuat oleh pabrik-pabrik pupuk dengan meramu bahan-bahan kimia anorganik berkadar hara tinggi

Salah satu upaya yang dilakukan dalam usaha tani tanpa mengggunakan bahanbahan kimia yang akan merusak lingkungan adalah dengan penggunaan mikroorganisme lokal (Mol) (Roidah,I.S.,2013). Sebuah teknologi dari masa lalu yang terlupakan kembali digali. Penyubur tanaman memanfaatkan mikro bioorganisme lokal menjadi solusi bagi petani lokal, menuju pertanian ramah lingkungan dan bebas dari pupuk dan obat-obatan kimiawi. Menurut USEPA, pupuk organik adalah manure atau kompos yang diaplikasikan ke tanaman sebagai sumber unsur hara (Funk 2014). Definisi tersebut pada intinya adalah bahwa pupuk organik mengadung unsur karbon dan unsur hara lainnya yang berkombinasi dengan karbon (Wiwik, et al. 2015). Pupuk organik merupakan pupuk yang berasal dari tumbuhan mati, kotoran hewan dan/atau bagian hewan dan/atau limbah organik lainnya yang telah melalui proses rekayasa, berbentuk padat atau cair, dapat diperkaya dengan bahan mineral, dan/atau mikroba yang bermanfaat untuk meningkatkan kandungan hara dan bahan organik tanah serta memperbaiki sifat fisik, kimia, dan biologi tanah (Permentan No. 70/Permentan/ SR.140/10/2011). Bahan Mol mudah didapatkan di Indonesia dan mudah diolah. Selain itu, Mol dapat menghemat 20-25\% dari total biaya produksi. MOL (mikroorganisme lokal) merupakankumpulan mikro-organisme yang bisa diternakkan, yang berfungsi sebagai starter dalam pembuatan bokasi atau kompos.Pemanfaatan limbah per-tanian seperti buah-buahan tidak layak konsumsi untuk diolah menjadi MOL dapat meningkatkan nilai tambah limbah, sertame-ngurangi pencemaran lingkungan. (Juanda, 2011)

Karbohidrat sebagai sumber nutrisi untuk mikroorganisme dapat diperoleh dari limbah organik, seperti air cucian beras, singkong, gandum, rumput gajah, dan daunan lainnya. Sumber glukosa berasal dari cairan gula merah, gula pasir dan air 
kelapa, serta sumber mikroorganisme berasal dari kulit buah yang sudah busuk, terasi, keong mas dan nasi basi (Anonim, 2013). Mol masih belum diketahui secara luas oleh petani, karena petani sendiri masih banyak yang menggunakan bahan-bahan kimia dalam berusaha tani dan juga dalam meningkatkan produksi pangan mereka.

\section{METODE}

Metode Kegiatan pengabdian kepada masyarakat dalam bentuk penyuluhan. Penyuluhan disampaikan dalam bentuk ceramah dan dialog interaktif atau diskusi interaktif kepada masyarakat. Kegiatan ini merupakan rangkaian kegiatan pengabdian kepada masyarakat yang terintegrasi dengan pelaksanaan kegiatan KKN Universitas Muhammadiyah Purworejo di desa Brengkol. Kegiatan ini dilaksanakan pada tanggal 30 Januari 2017, bertempat di aula balai desa Brengkol kecamatan Pituruh.

Sebagai mitra dalam kegiatan pengabdian ini adalah seluruh penduduk yang bermukim di kompleks perumahan yang ada di kelurahan desa Brengkol. Mitra yang diikut sertakan dalam kegiatan ini adalah mereka yang diharapkan dapat menjadi motivator dan inovator untuk memperluas penerapan program pemanfaatan limbah organik sebagai bahan pembuatan MOL yang disampaikan. Selain itu, akan diikut sertakan kelompok tani, Gapoktan, dan Karangtaruna kelurahan, karena mereka merupakan unjung tombak untuk program pemberdayaan petani di RW nya masingmasing.

Prosedur pada kegiatan pengabdian ini adalah diawali dengan kegiatan observasi, kemudian pelaksanaan dengan pemberian materi penyuluhan, pada kegiatan ini akan dijelaskan manfaat MOL untuk tanaman dan menjelakan cara pembutan MOL. Mengintroduksikan bahan limbah organik yang dijadikan sebagai bahan pembuatan MOL dan pelatihan pembuatan MOL dengan petani secara langsung kepada peserta, lalu dilanjutkan tanya jawab seputar materi pembuatan mikroorganisme lokal.

Data pada kegiatan pengabdian ini diperoleh berdasarkan hasil penyuluhan, pelatihan dan tanya jawab yang dilaksanakan antara pemateri dengan peserta. Data yang telah diperoleh dari hasil tanya jawab dan tanggapan dari seluruh peserta yang mengikuti kegiatan pengabdian, selanjutnya data tersebut kemudian dilakukan analisis dengan analisis deskriptif.

\section{HASIL DAN PEMBAHASAN}

Peran MOL sebagai dasar komponen pupuk mikroba tidak hanya bermanfaat bagi tanaman namun juga bermanfaat sebagai agen dekomposer bahan organik limbah pertanian, limbah rumah tangga dan limbah industri. Biofertilizer berbasis mikroorganisme diharapkan mampu memperbaiki struktur dan tekstur tanah, biologi tanah serta menyeimbangkan kembali ekosistem pertanian, baik lingkungan rhizosfer maupun lingkungan lingkungan diatas rhizosfer. 
Keunggulan utama penggunaan MOL adalah murah bahkan tanpa biaya, selain itu ada beberapa keuntungan: mendukung pertanian ramah lingkungan, dapat mengatasi permasalahan pencemaran limbah pertanian dan limbah rumah tangga, pembuatan serta aplikasinya mudah dilakukan, mengandung unsur kompleks dan mikroba yang bermanfaat dalam produk pupuk dan dekomposer organik yang dihasilkan, memperkaya keanekaragaman biota tanah, memperbaiki kualitas tanah dan tanaman.

a. Pembuatan Microorganisme Local

Bahan dan Alat

a) Bahan (air leri 5L, molases 1 botol, buah pisang busuk 10 buah, air 5l, jerigen 1 buah , EM-4, botol 1 buah dan slang $5 \mathrm{~cm}$ ).

b) Alat ( pisau, blender, ember, torong, gelas ukur dan solder).

b. Langkah Pembuatan MOL

a) Persiapkan semua bahan dan alat.

b) Lubangi tutup derigen dengan solder.

c) Potong slang ukuran $5 \mathrm{~cm}$.

d) Lubang tutup botol plastik dengan solder.

e) Blender buah pisang busuk sampai halus.

f) Masukan air leri kedalam ember dan campurkan buah pisang yang sudah diblender, masukan 2 tutup botol molases, masukan 2 tutup EM-4 aduklah sampai rata semua.

g) Masukan adukan bahan tersebut kedalam derigen dan tutup sampai rapat.

h) Masukan slang ke dalam lubang tutup derigen.

i) Masukan air kedalam botol, masukan slang kedalam tutup botol kemudian tutup sampai rapat.

j) MOL difermentasi sekitar 12 hari.

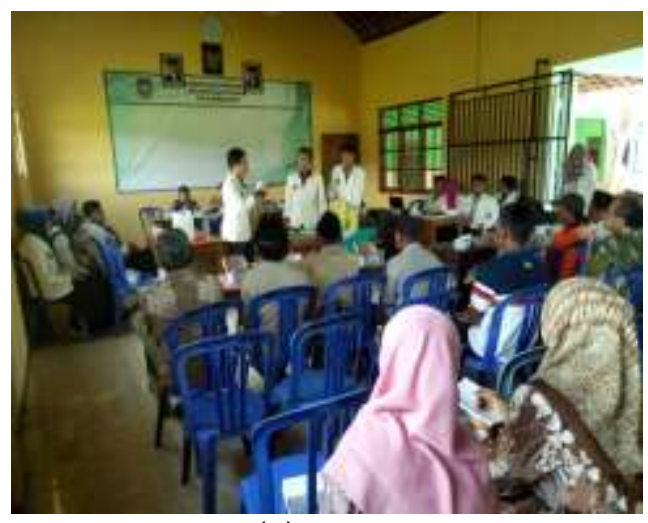

(a)

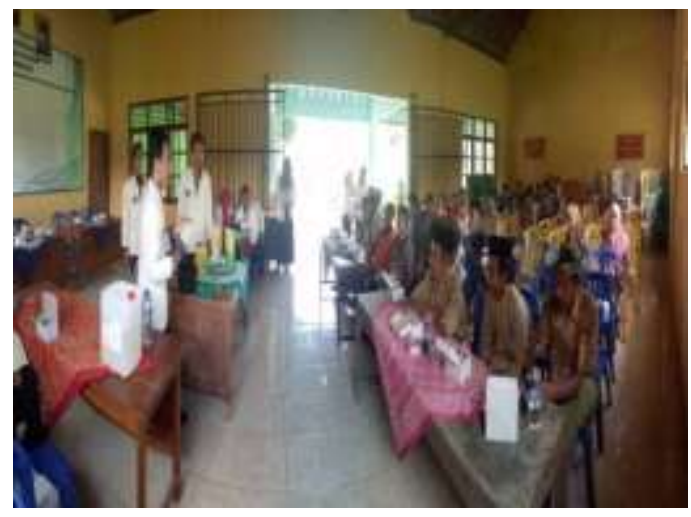

(b) 


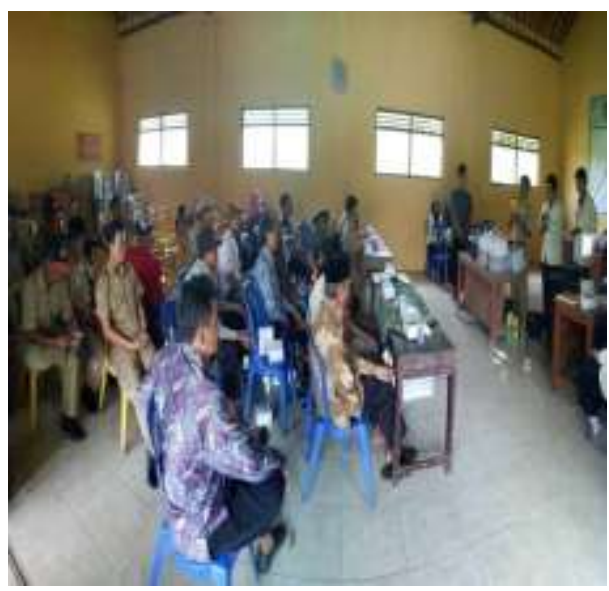

(c)

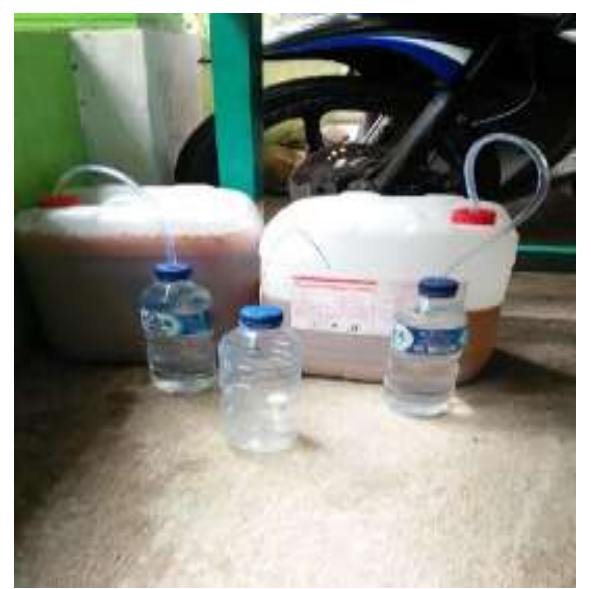

(d)

Gambar 1. Dokumentasi Kegiatan (a) dan (b) Penyuluhan dan Pelatihan Pembuatan Microorganisme Local, (c) Pembuatan MOL, (d) Proses Fermentasi

Gambar 1 merupakan dokumentasi kegiatan pengabdian pada masyarakat ini dilaksanakan pada tanggal 25 Januari 2017, bertempat di aula balai desa Brengkol kecamatan Pituruh, pukul 08.00 WIB. Kegiatan ini dihadiri oleh perangkat desa, petani, karang taruna dan tohoh masyarakat. Peserta yang mengikuti kegiatan ini antusias dan sangat termotivasi dengan penyampaian materi dan praktik. Hal ini terlihat dengan adanya penyampaian beberapa permasalahan, baik yang berhubungan dengan materi maupun diluar materi penyuluhan. Respon yang cepat dari petani pada saat penyuluhan ketika terdapat materi yang kurang bisa dipahami oleh mereka. Sebagian peserta penyuluhan mencatat hal-hal penting terkait materi penyuluhan yang disampaikan. Selain itu, petani juga menyampaikan kendala-kendala yang dihadapinya. Dengan dilakukannya praktik latihan pembuatan mikroorganisme lokal secara langsung di hadapan peserta yang hadir, akan menjadi lebih mudah ditangkap dan diingat oleh para peserta, sehingga diharapkan nantinya bisa mempraktikkannya sendiri.

\section{KESIMPULAN}

Kegiatan penyuluhan dan pelatihan pembuatan mikroorganisme lokal yang dilaksanakan di desa Brengkol, kecamatan Pituruh mendapat antusiasme masyarakat terutama petani dan mendapat sambutan yang baik karena program penyuluhan dan pelatihan pembuatan mikroorganisme lokal sesuai dengan kebutuhan masyarakat setempat.

Berdasarkan simpulan tersebut dapat dirumuskan rekomendasi sebagai berikut: perlu upaya memanfaatkan limbah organik, baik berupa limbah pertanian, limbah rumah tangga maupun limbah peternakan, yang selanjutnya bertujuan untuk memberi makanan pada tanaman untuk bertumbuh dengan baik tanpa menggukanakan bahan kimia. Limbah organik tersebut dapat dimanfaatkan untuk membuat mikroorganisme lokal secara konsisten dan berkelanjutan. 


\section{DAFTAR PUSTAKA}

Anonim. 2013. http://erepo.unud.ac.id/8381/3/d5ac4e31405451902a4ae35eda1368a4.pdf. Internet. Diakses Februari 2017.

BP4KSukabumi, 2011.Cara Pembuatan Mikroorganisme Lokal. http://bp4kkabsukabumi.net. Diakses Februari 2017.

Candra, Rudi Aditama, Nia Kurniawan. (2013). Struktur Komunitas Serangga Nokturnal Areal Pertanian Padi Organik pada Musim Penghujan di Kecamatan Lawang, Kabupaten Malang. Biotropika: Journal of Tropical Biology, 1(4).

Darwin H Pangaribuan, dkk. (2013). Prosding Seminar Hasil Pengabdian Masyarakat Universitas Lampung. 1-7. ISBN: 987-602-99908-0-5. Retrived from: http://repository.lppm.unila.ac.id/3746/1/Darwin\%20H\%20Pangaribuan\%20Pengabdian\% 20MOL\%20Sidomulyo\%20OK.pdf

Funk, R.C. Comparing organic and inorganic fertilizer. http://www.newenglandisa.org/FunkHandoutsOrganicInorganicFertilizers.pdf.

Hartatik, Wiwik, Husnain, dan Ladiyani R. Widowati. (2015). Peranan Pupuk Organik dalam Peningkatan Produktivitas Tanah dan Tanaman. Jurnal Sumberdaya Lahan, 9(2); 107-120

P2APH JOMBANG. 2011. Selamatkan Ekosistem Pertanian. Pemanfaatan MOL (Mikroorganisme Lokal).https://p2aph.wordpress.com/2011/03/24/pemanfaatan-molmikroorganisme-lokal/ diposting 24 Maret 2011.

Peran dan pemanfaatan mikroorganisme lokal (MOL) mendukung pertanian organik. http://sulsel.litbang.pertanian.go.id/ind/images/mendukung-pertanian-organik.pdf

Peraturan Menteri Pertanian No. 70/Permentan/SR.140/10/2011 tentang Pupuk Organik, Pupuk Hayati, dan Pembenah Tanah.

Roidah, I. S. (2013). Manfaat penggunaan pupuk organik untuk kesuburan tanah. Jurnal Bonorowo, 1(1), 30-43.

Juanda,Irfan, dan Nurdiana. (2011). Pegaruh Metodedan Lama Fermentasi terhadap Mutu Mol (Mikroorganisme Lokal). Jurnal Floratek, 6: 140-143. 